\title{
Analysis of RNA transcripts for HLA class II genes in human small intestinal biopsies
}

\author{
B A VOLK, D A BRENNER, AND M F KAGNOFF \\ From the Department of Medicine, M-023-D, University of California, San Diego, La Jolla, CA 92093, USA
}

SUMmaRY Studies of the expression of selected genes within the intestinal mucosa will provide important new information about physiologic and pathological processes that effect mucosal growth, differentiation, and function. To study gene expression in the gut, we developed a method to obtain sufficient undegraded RNA from human endoscopic intestinal biopsy specimens for Northern and slot blot analysis. To verify the method, we examined the differential expression of HLA class II genes in small intestinal mucosa. Levels of RNA transcripts for HLA-DR, -DP, and -DQ $\alpha$ and $\beta$ chains were assessed in freshly isolated endoscopic intestinal mucosal biospy specimens and compared with levels in Epstein-Barr virus transformed B cells from the same individuals. Sufficient undegraded cellular RNA with distinct $28 S$ and $18 S$ ribosomal bands could be obtained from as few as two 2-3 mm endoscopic biopsies. Using chain and locus specific cDNA probes, HLA-DR, -DP, and -DQ subregion genes were shown to be expressed in intestinal mucosa, with the relative magnitude of RNA transcripts being DR $>D P>D Q$. The same hierarchy of expression was seen for EBVtransformed B cell lines. This method, in conjunction with the polymerase chain reaction for amplifying specific RNA transcripts and in situ hybridisation methods for the cellular localisation of RNA transcripts, will enable studies on the regulation of gene expression in the intestinal mucosa.

The differential expression of genes within the intestinal mucosa determines normal and pathological development and function in the gut. Nonetheless, it has been difficult to study gene regulation in human gut because of difficulty in obtaining sufficient quantities of tissue and a lack of appropriate in vivo or in vitro models.

Human HLA class II genes are located in the HLA-D region of the major histocompatibility complex (MHC) on chromosome 6. The HLA class II genes encode three major sets of HLA class II antigens that are expressed on the cell surface; HLADR, -DP, and -DQ. The HLA class II antigens are heterodimers, each consisting of an $\alpha$ and $\beta$ chain.' HLA class II antigens are found normally on cells of the lymphoid system, including B lymphocytes, macrophages/dendritic cells, and activated $T$ cells. ${ }^{2}$ The expression of HLA class II molecules also can be stimulated, particularly during inflammation, on other human non-lymphoid cell types, including

Address for correspondence: Dr Martin F. Kagnoff. University of California. San Diego Department of Medicine. M-023-D. La Jolla, CA 92093. USA.

Accepted for publication 4 January 1989. epithelial cells - for example, biliary, gastric, small and large intestinal, thyroid epithelial cells, and vascular endothelial cells. ${ }^{3-5}$

The HLA class II antigens are highly polymorphic and, as such, are important in the presentation of a wide array of antigenic peptides to T lymphocytes of the CD4 lineage. ${ }^{6}$ Several diseases of a presumed autoimmune nature, including coeliac disease, have a significant association with specific HLA antigens and HLA class II haplotypes. ${ }^{78}$ Further, the inappropriate expression of HLA class II antigens, on cells that normally do not express those molecules, has been postulated to be important in the pathogenesis of several autoimmune diseases that have strong HLA class II associations." "10

Antigens coded by HLA-DR subregion genes have been shown on normal villous absorptive epithelial cells of the human small intestine by immunohistochemical and immunoelectronmicroscopic methods. ${ }^{11-14}$ Further, patients with coeliac disease, compared with controls, have greater expression of HLA-DR on epithelial cells in the crypt region after a gluten challenge..$^{15-18}$ Little is known, however, regarding the mechanism by which HLA-DR, -DP, 
and -DQ molecules are differentially regulated in the gut or the function of HLA class II antigens in the intestinal mucosa. ${ }^{19-21}$

Immunohistochemistry permits a qualitative analysis of the morphologic distribution of antigens in the intestine. Such approaches are not well suited, however, for investigations of gene regulation and the factors affecting gene expression in the intestine. The latter require several complementary approaches, one of which is the ability to directly detect and quantify specific RNA transcripts within the intestinal mucosa. A serious obstacle to such studies has been the limited amount of small intestinal tissue readily available for study in the absence of surgery, coupled with the problem of rapid degradation of cellular RNA by RNAses in tissue obtained at surgery or post-mortem where there is a delay in tissue processing. Using HLA class II genes as a model, we report herein that sufficient undegraded cellular RNA can be obtained from as few as two intestinal endoscopic biopsy specimens for Northern and slot blot analysis of RNA transcripts in small intestinal mucosa.

\section{Methods}

PATIENTS AND CELL LINES

Mucosal biopsies were obtained from the second portion of the duodenum of normal subjects at the time of fibreoptic gastroduodenoscopy. Biopsies were placed immediately in guanidinium isothiocyanate. Concurrently, $30-50 \mathrm{ml}$ of blood was drawn into sodium heparin-containing tubes $(15 \mathrm{U} / \mathrm{ml})$, and the peripheral blood lymphocytes were separated by Ficoll-Hypaque gradient centrifugation (Pharmacia, Fine Chemicals, Piscataway, NJ). Lymphoblastoid B-cell lines were initiated as previously described. ${ }^{22}$ Briefly, $5 \times 10^{6}$ peripheral blood lymphocytes were cultured in RPMI-1640 media, supplemented with 2 $\mathrm{mM}$ glutamine, $100 \mathrm{U} / \mathrm{ml}$ penicillin, $100 \mu \mathrm{g} / \mathrm{ml}$ streptomycin and $10 \%$ fetal calf serum, to which supernatant from an Epstein-Barr virus shedding cell line, 1437 , and $2 \mu \mathrm{g} / \mathrm{ml}$ cyclosporin A were added.

ISOLATION OF RNA AND NORTHERN BLOT

HYBRIDISATION

RNA preparation and Northern blot analysis were performed as described before, ${ }^{2.324}$ with the following modifications. To obtain cellular RNA, mucosal biopsies were placed immediately at the bedside in $3 \mathrm{ml}$ guanidinium isothiocyanate containing 2-mercaptoethanol, and then homogenised with a Polytron homogeniser (Brinkmann Instruments, Inc, Orange, CA) on ice for three to 10 seconds. Specimens were then centrifuged for three minutes to minimise contamination with pieces of connective and adipose tissue, after which supernatants were gently forced through a no. 22 gauge needle with a sterile syringe. RNA was prepared from supernatants by the guanidinium isothiocyanate caesium chloride procedure, ${ }^{23}$ followed by phenol/chloroform extraction. ${ }^{25}$ For Northern blot analysis, ${ }^{24}$ RNA samples $(5-10 \mu \mathrm{g})$ were dissolved in $50 \%$ formamide and $2.2 \mathrm{M}$ formaldehyde and electrophoresed in a $2.2 \mathrm{M}$ formaldehyde $/ 1 \%$ agarose gel in $20 \mathrm{mM}$ morpholinopropane sulphonic acid buffer. RNA samples were transferred by capillary blotting in $20 \times \mathrm{SSC}(1 \times \mathrm{SSC}=150 \mathrm{mM} \mathrm{NaCl}, 15 \mathrm{mM}$ trisodium citrate, $\mathrm{pH}$ 6) to Biotrans nylon membranes (ICN Corp, Irvine, CA) according to manufacturer's instructions. Air dried filters were baked in a vacuum oven for two hours at $80^{\circ} \mathrm{C}$ and prehybridised for four to six hours at $42^{\circ} \mathrm{C}$ in $50 \%$ formamide, $5 \times \mathrm{SSC}, 50$ $\mathrm{mM} \mathrm{NaPO} 4 \mathrm{pH}^{2} \cdot 5,0 \cdot 1 \%$ SDS, $250 \mu \mathrm{g} / \mathrm{ml}$ sonicated salmon sperm DNA, and $5 \mu \mathrm{g} / \mathrm{ml}$ polyuridylic acid (Pharmacia Co, Piscataway, NJ). Hybridisation was performed for $12-16 \mathrm{~h}$ at $42^{\circ} \mathrm{C}$ in fresh prehybridisation solution with the addition of $10 \%$ dextran sulfate and radiolabelled probe $\left(10^{6} \mathrm{cpm} / \mathrm{ml}\right)$. ${ }^{32} \mathrm{P}$ radiolabelled cDNA probes were prepared by the random priming method of Feinberg et $^{l^{2 h}}$ using high specific activity $\left.\alpha^{-32} \mathrm{P}\right] \mathrm{dCTP}(3000 \mathrm{Ci} / \mathrm{mmol})$. Final washes $(2 \times)$ were done at a stringency of $0 \cdot 1 \times \mathrm{SSC}$ at $60^{\circ} \mathrm{C}$ for $30 \mathrm{~min}$ each. Nylon filters were exposed to Kodak XAR-5 $x$-ray film with an intensifying screen for $12-72 \mathrm{~h}$. For rehybridisation with different probes, blots were stripped in $50 \%$ formamide, $5 \mathrm{mM}$ Trishydrochloric acid ( $\mathrm{pH} \mathrm{7.0)}$ and $1 \mathrm{mM}$ EDTA, at $65^{\circ} \mathrm{C}$ for two 30 min periods. Each blot could be rehybridised five to eight times. Slot blots on nitrocellulose paper were treated similarly after two-fold serial dilutions of RNA.

HLA CLASS II GENE CDNA PROBES

HLA-DR, -DQ, and -DP $\alpha$ and $\beta$ chains and locus specific cDNA's were kindly provided by Dr PiatierTonneau. ${ }^{27}$ Hybridisation probes used were as follows: a 460 bp Pst I fragment of LB 24 cDNA, a DP $\alpha$ chain cDNA; a 500 bp Rsa I-Sac I fragment of pDCH1 cDNA, a DQ $\alpha$ chain cDNA; a 700 bp Pst IPst I fragment of pDRH-7, a DR $\alpha$ chain cDNA; a 130 bp Pst I-Rsa I fragment from the $3^{\prime}$ UT region of pDR $\beta$, a DR $\beta 1$ chain cDNA; a 497 bp Pst I fragment of the $3^{\prime}$ UT region of the DC3 $\beta$ gene, a DQ $\beta$ genomic clone; a 370 bp Sac I-Hinc II fragment of the $3^{\prime}$ UT region of DP4 $\beta$, a DP $\beta$ genomic clone and a $300 \mathrm{bp}$ Ava II-Hind III fragment of the $3^{\prime}$ UT region of PMT3 $\beta$-3 (MT), a DR $\beta-3$ genomic clone..$^{.7} \mathrm{~A}$ human $\alpha$ tubulin cDNA, was provided by Dr $N$ J Cowan. ${ }^{2 \times}$ Hybridisation probes were tested and shown to be chain and locus specific by hybridisation of the inserts with ${ }^{32} \mathrm{P}$ nick-translated whole plasmid. 


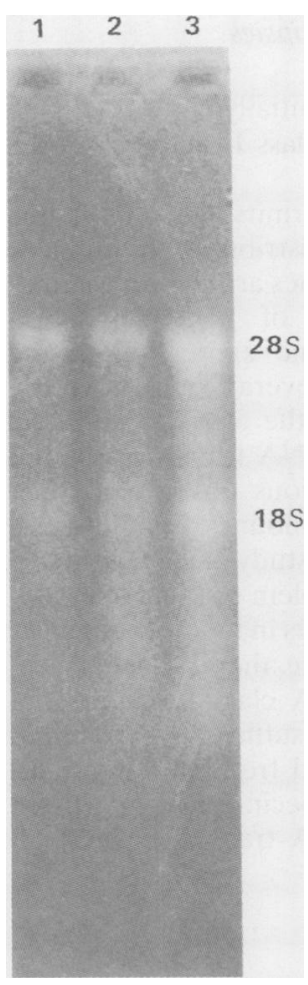

Volk, Brenner, and Kagnoff

\section{Results}

We obtained a yield of approximately $40 \mu \mathrm{g}$ of total RNA from two 2-3 mm endoscopic biopsy specimens, sufficient for Northern and slot blot analysis. The pattern of undegraded cellular RNA with distinct $28 \mathrm{~S}$ and $18 \mathrm{~S}$ ribosomal RNA bands is shown in Figure 1. A representative Northern blot, using RNA from intestinal biopsies or EBV-transformed B cell lines from the same individuals and hybridised with HLA class II $\alpha$ chain probes, is shown in Figure 2. Intestinal biopsies and the EBV B cell lines expressed high levels of DR- $\alpha$ transcripts. Similarly, DP- $\alpha$ transcripts were highly expressed in intestinal biopsy specimens and EBV cell lines. RNA transcripts for DQ- $\alpha$ were expressed at a lower level both in the intestinal biopsies and EBV cell lines. Parallel results were obtained for HLA-DR $\beta, D P \beta$, and DQ $\beta$ chains (not shown). Among the HLA class II RNA transcripts, three different patterns were observed; a single RNA band was seen for DR- and DP- $\alpha(1 \cdot 5$ kb) (Fig. 2) and DR- $\beta$ and DP- $\beta$ (not shown). Two bands were seen for DQ- $\beta(1.3 \mathrm{~kb}$ and $1.7 \mathrm{~kb}$ ) (not shown) and three bands were seen for DQ- $\alpha(1 \cdot 3,1 \cdot 5$, and $1.7 \mathrm{~kb}$ ) (Fig. 2). Polymorphism in the size of DQ- $\alpha$ RNA transcripts is known to correlate with the

Fig. 2 Northern blot analysis of RNA (10 $\mathrm{gg} /$ lane) isolated from endoscopic small intestinal mucosal biopsy specimens (top) or $E B V B$ cell lines (bottom) from three different healthy individuals (Lanes 1-3). Blots were probed with $H L A-D R$, $-D P$, or - $D Q \alpha$ chain $C D N A$ 's or with the $\alpha$-tubulin $c D N A$, as indicated on the right. Intestinal biopsies and EBV $B$ cell lines expressed high levels of $D R$ - $\alpha$ transcripts. Similarly, $D P-\alpha$ was highly expressed in the intestinal biopsies and EBV B cell lines. RNA transcripts for $D Q$ - $\alpha$ were expressed at a somewhat lower level both in the intestinal biopsies and EBV B cell lines.

Fig. 1 Pattern of undegraded cellular RNA obtained from normal human small intestinal biopsies of three different individuals with distinct $28 S$ and $18 S$ ribosomal bands as indicated.

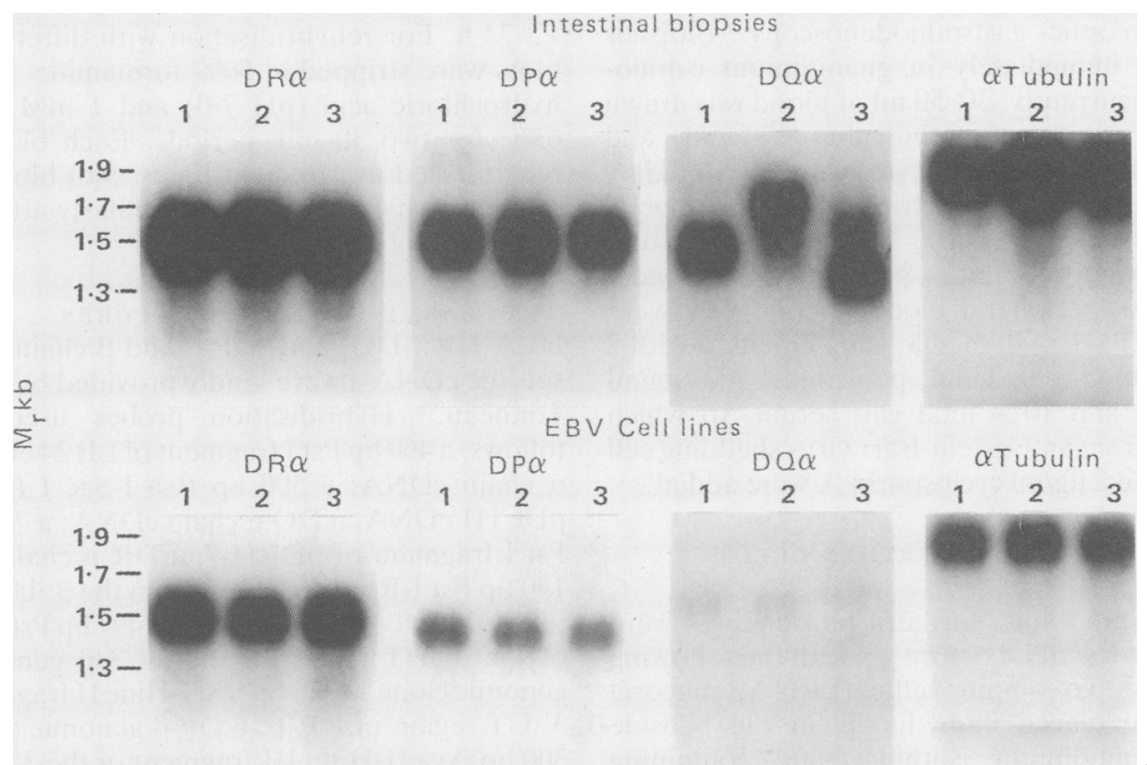




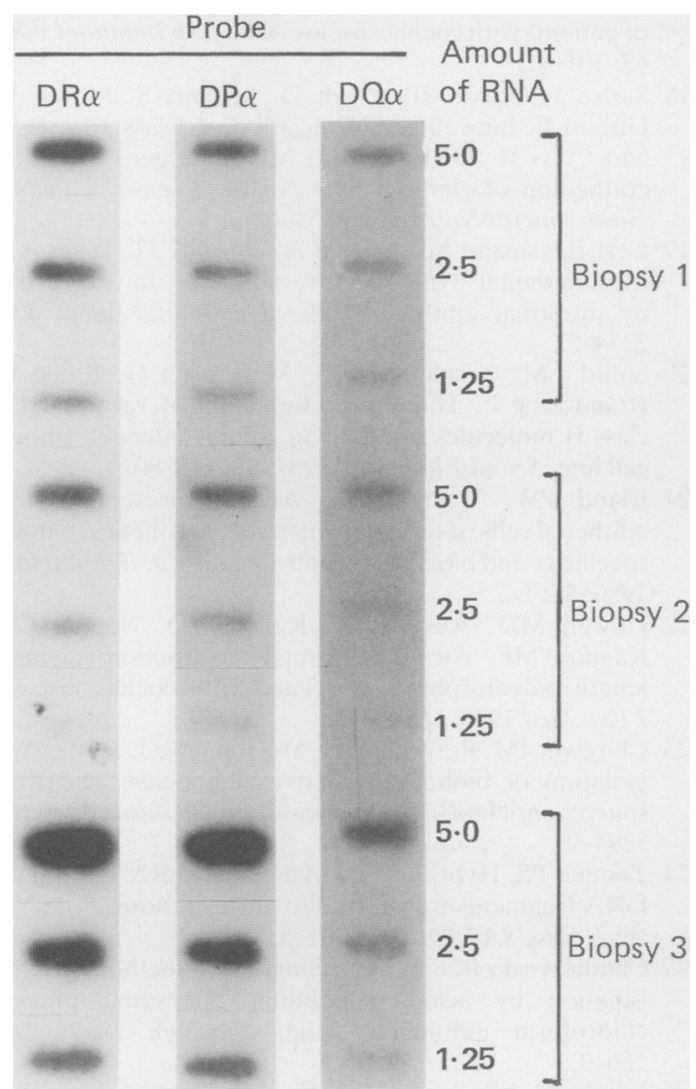

Fig. 3 Slot blot analysis of RNA from intestinal biopsies of three different individuals probed with $H L A-D R$, $-D P$, or $-D Q-\alpha$ chain cDNAs. Slots contain serial two-fold dilutions of $R N A$. Hybridisation signals are $D R>D P>D Q$.

presence in different individuals of different HLADR allelic specificities, ${ }^{27}$ whereas the two constant size messages for DQ- $\beta$ are present in each individual and appear to correspond to alternate splicing products with the use of different polyadenylation sites. ${ }^{2729}$ The $\alpha$-tubulin probe detected a single $\alpha$-tubulin transcript at $1.9 \mathrm{~kb}$.

Slot blots containing two-fold serial dilutions of total RNA from each biopsy specimen hybridised to the HLA-DR, -DP, and -DQ $\alpha$ cDNAs are shown in Figure 3. When normalised to the $\alpha$-tubulin signal, the hierarchy of signals was DR $>$ DP $>$ DQ for both $\alpha$ and $\beta$ chain transcripts.

\section{Discussion}

Sufficient undegraded cellular RNA for Northern and slot blot analysis can be isolated from as few as two small intestinal endoscopic biopsy specimens.
The reproducible success of this procedure was at first surprising, given the problems we anticipated from RNA degradation by cellular RNAses in that site. In fact, our initial attempts to obtain RNA using a single step extraction method ${ }^{25}$ were not successful. Our success with the method reported herein appears to depend on the rapid transfer of biopsy specimens to guanidinium isothiocyanate, the use of small volumes, and care to avoid contaminating RNAses during harvesting of samples from the $\mathrm{CsCl}$ gradients.

To verify the utility of our method, we examined HLA Class II gene expression in intestinal mucosa as assessed by the level of mRNA transcripts for HLADR, DP, and DQ $\alpha$ and $\beta$ chains. The present report demonstrates that HLA-DR, -DP, and -DQ subregion genes are expressed by cells within the normal intestinal mucosa. Quantitative analysis of slot blots revealed that the relative order of the steady state mRNA levels are DR $>$ DP $>$ DQ. Previously, it has been controversial as to whether HLA-DP and -DQ class II antigens are expressed by cells in this site in the absence of disease. $11121 ;$ in

We note that the contribution to the expression of HLA class II RNA transcripts by absorptive epithelial cells compared with B lymphocytes and other mononuclear cells in the lamina propria" was not being assessed by this approach. In contrast with genes that are expressed selectively in defined cell types - for example, epithelial cells. goblet cells. enteroendocrine cells, molecules like those encoded by HLA genes are expressed by multiple cell types in the intestinal mucosa. For genes expressed by multiple cell types, the quantitative measurement of RNA transcripts in extracts of whole mucosa, as described herein, can be complemented by in situ hybridisation studies ${ }^{31}$ to document the cell type(s) producing the RNA transcripts being studied. In situ hybridisation, however, simply provides a qualitative picture of the cells that are expressing a particular gene. Filter hybridisation methods, as presented here, are required to analyse the relative levels of specific transcripts in biopsies from the normal intestinal mucosa and alterations in gene expression in different disease states. Finally, we note that total cellular RNA, as prepared herein, can serve as a template for the synthesis of single strand cDNA, which subsequently can be used to amplify specific transcripts by the polymerase chain reaction."

This work was supported by NIH grant DK35108. B A Volk was a recipient of a research grant of the Deutsche Forschungsgemeinschaft Vo 264-3.

We thank S Lai for preparation of the manuscript. Published in part in abstract form. 


\section{References}

1 Korman AJ, Boss JM, Spies T, Sorrentino R, Okada K, Strominger JL. Genetic complexity and expression of human class II histocompatibility antigens. Immunol Rev 1985; 85: 45-86.

2 Radka SF, Charron DJ, Brodsky FM. Review: Class II molecules of the major histocompatibility complex considered as differentiation markers. Hum Immunol 1986; 16: $390-400$.

3 Daar AS, Fuggle SV, Fabre JW, Ting A, Morris PJ. The detailed distribution of MHC class II antigens in normal human organs. Transplantation 1984; 38: 293-8.

4 Selby WS, Janossy G, Mason DY, Jewell DP. Expression of HLA-DR antigens by colonic epithelium in inflammatory bowel disease. Clin Exp Immunol 1983; 53: $614-8$.

5 Spencer J, Finn T, Isaacson PG. Expression of HLADR antigens in epithelium associated with lymphoid tissue in the human gastrointestinal tract. Gut 1986; 27: 153-7.

6 Malissen B, Peele Price M, Goverman JM, et al. Gene transfer of HLA class II genes: antigen presentation by mouse fibroblast and hamster B-cell lines. Cell 1984; 36: 319-28.

7 Howell MD, Smith JR, Austin RK, et al. An extended HLA-D region haplotype associated with celiac disease. Proc Natl Acad Sci USA 1988; 85: 222-6.

8 Alper CA. Fleischnick E, Awdeh Z, Katz AJ, Yunis EJ. Extended major histocompatibility complex haplotypes in patients with gluten-sensitive enteropathy. J Clin Invest 1987; 79: 251-6.

9 Lo D, Burkly LC, Widera G, et al. Diabetes and tolerance in transgenic mice expressing class II MHC molecules in pancreatic beta cells. Cell 1988; 53: 159-68.

10 Bottazo GF, Todd I, Mirakian R, Belfiore A, PujolBorrell R. Organ-specific autoimmunity: a 1986 overview. Immunol Rev 1986; 94: 137-69.

11 Natali P, Bigotti A, Cavalieri M, et al. Gene products of the HLA-D region in normal and malignant tissues of nonlymphoid origin. Hum Immunol 1986; 15: 220-33.

12 Gorvel J, Sarles J, Maroux S, Olive D, Mawas C. Cellular localization of class I (HLA-A,B,C) and class II (HLA-DR and DQ) MHC antigens on epithelial cells of normal human jejunum. Biol Cell 1984; 52: 249-52.

13 Scott H, Solheim BG, Brandtzaeg P. Thorsby E. HLADR-like antigens in the epithelium of the human small intestine. Scand J Immunol 1980; 12: 77-82.

14 Hirata I, Austin LL, Blackwell WH, Weber JR. Dobbins WO. III. Immunoelectron microscopic localization of HLA-DR antigen in control small intestine and colon and in inflammatory bowel disease. Dig Dis Sci 1986; 31: 1317-30.

15 Marley NJE, Macartney JC, Ciclitira PJ. HLA-DR, DP, and DQ expression in small intestine of patients with cocliac disease. Clin Exp Immunol 1987; 70: 386-93.

16 Scott H, Sollid LM, Fausa O, Brantzaeg P, Thorsby E. Expression of major histocompatibility complex class II subregion products by jejunal epithelium in patients with cocliac disease. Scand J Immunol 1987; 26: 563-71.

17 Ciclitira PJ, Nelufer JM, Ellis HJ, Evans DJ. The effect of gluten on HLA-DR in the small intestinal epithelium of patients with coeliac disease. Clin Exp Immunol 1986: 63: $101-4$.

18 Sarles J, Gorvel JP. Olive D. Maroux S. Mawas C. Giraud F. Subcellular localization of Class I (A,B,C) and Class II (DR and DQ) MHC antigens in jejunal epithelium of children with coeliac disease. $J$ Pediatr Gastroenterol Nutr 1987; 6: 51-6.

19 Cerf-Bensussan N, Quaroni A. Kurnick JT, Bhan AK. Intraepithelial lymphocytes modulate Ia expression by intestinal epithelial cells. J Immunol 1984: 132: 2244-52.

20 Sollid LM, Guadernack G, Markussen G, Kvale D. Brandtzaeg $P$. Thorsby $E$. Induction of various HLA class II molecules in a human colonic adenocarcinoma cell line. Scand J Immunol 1987; 25: 175-80.

21 Bland PW, Warren LG. Antigen presentation by epithelial cells of the small intestine. I. Kinetics, antigen specificity and blocking by anti-Ia antisera. Immunology 1986; 58: $1-7$.

22 Howell MD, Austin RK, Kelleher D. Nepom GT, Kagnoff MF. An HLA-D region restriction fragment length polymorphism associated with coeliac disease. J Exp Med 1986: 164: 333-8.

23 Chirgwin JM, Przybyla AE, McDonald RJ, Rutter WJ. Isolation of biologically active ribonucleic acid from sources enriched in ribonuclease. Biochemistry 1979; 18: 5294-9.

24 Thomas PS. Hybridization of denatured RNA and small DNA fragments transferred to nitrocellulose. Proc Natl Acad Sci USA 1980); 77: 5201-5.

25 Chomczynski P. Sacchi N. Single-step method of RNA isolation by acid guanidinium thiocyanate-phenolchloroform extraction. Anal Biochem 1987; 162: 156-9.

26 Feinberg AP, Vogelstein B. A technique for radiolabelling DNA restriction endonuclease fragments to high specific activity. Anal Biochem 1983; 132: 6-13.

27 Piatier-Tonneau D, Turmel P. Auffray C. Charron D. Construction of chain- and locus-specific HLA class II DNA probes study of HLA class II transcripts in leukemias. J Immunol 1986; 137: 2050-6.

28 Cowan NJ, Dobner PR. Fuchs EV. Cleveland DW. Expression of human $\alpha$-tubulin genes: Interspecies conservation of $3^{\prime}$ untranslated regions. Mol Cell Biol 1983; 3: $1738-45$.

29 Briata P. Radka SF. Sartoris S, and Lee JS. Alternative splicing of HLA-DQ beta-chain proteins: allelic polymorphism in splicing and polyadenylation sites. Proc Natl Acad Sci USA 1989: 86: 10)(13-7.

30) Selby WS, Pulter LW. Hobbs S, Jewell DP, Janossy G. Heterogeneity of HLA-DR-positive histiocytes in human intestinal lamina propria: A combined histochemical and immunohistological analysis. J Clin Pathol 1983: 36: 379-84.

31 Nelson JA, Wiley CA, Reynolds-Kohler CR, Reese CE, Margaretten W. Levy JA. Human immunodeficiency virus detected in bowel epithelium from patients with gastrointestinal symptoms. Lancet 1988; i: 259-62.

32 Saiki RK, Gelfand DH, Stoffel S, et al. Primer-directed enzymatic amplification of DNA with a thermostable DNA polymerase. Science 1988; 239: 487-91. 